
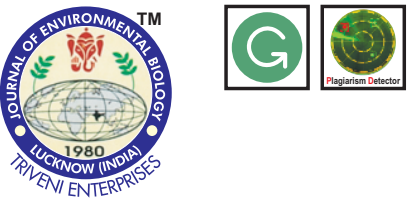

DOI : http://doi.org/10.22438/jeb/38/5/MRN-384
Journal of Environmental Biology

ISSN: 0254-8704 (Print) ISSN: 2394-0379 (Online) CODEN: JEBIDP

\title{
Breeding performance of indigenous \\ carp, Labeo dero in captivity under cold water condition of Uttarakhand, India
}

\section{Authors Info}

N.N. Pandey*, M. Gupta,

R. Singh, S. Ali, R.S. Haldar,

P. Kumar and A.K. Singh

Directorate of Coldwater Fisheries Research (ICAR),

Bhimtal - 263 136, India

*Corresponding Author Email : nityanfish@yahoo.co.in

Key words

Breeding performance,

Diversification,

Gonadosomatic index,

Labeo dero,

Ovaprim hormone

\section{Publication Info}

Paper received : 15.06 .2016

Revised received : 14.10 .2016

Re-revised received : 10.12 .2016

Accepted : 16.02.2017

\section{Abstract}

Aim : To study the breeding performance of indigenous carp, Labeo dero in captivity under cold water condition.

Methodology : Rearing of adult fish in pond condition, observation of gonadal maturity and GSI, standardization of optimum dose of hormone, recording of breeding parameters such as fecundity, fertilization rate, hatching percentage, incubation period, egg size and hatchling size were studied.

Results : Single intramuscular dose of synthetic hormone, ovaprim @ $0.7 \mathrm{ml} \mathrm{kg}^{-1}$ body weight for female and $0.3 \mathrm{ml} \mathrm{kg}^{-1}$ body weight for male resulted in successful spawning of $L$. dero without post spawning mortality at $18^{\circ}-22^{\circ} \mathrm{C}$ water temperature. Observed relative fecundity was $1,47,343 \mathrm{eggs}^{-1}$ with fertilization rate of $90 \%$ and hatching rate $78 \%$. The average diameter of the fertilized egg was $1.6-2.8 \mathrm{~mm}$.

Interpretation : Successful induced breeding of captive reared $L$. dero at $18^{\circ}-22^{\circ} \mathrm{C}$ water temperature was observed. These findings would be helpful in seed production of $L$. dero, which can be used for natural stock augmentation and culture of this species.

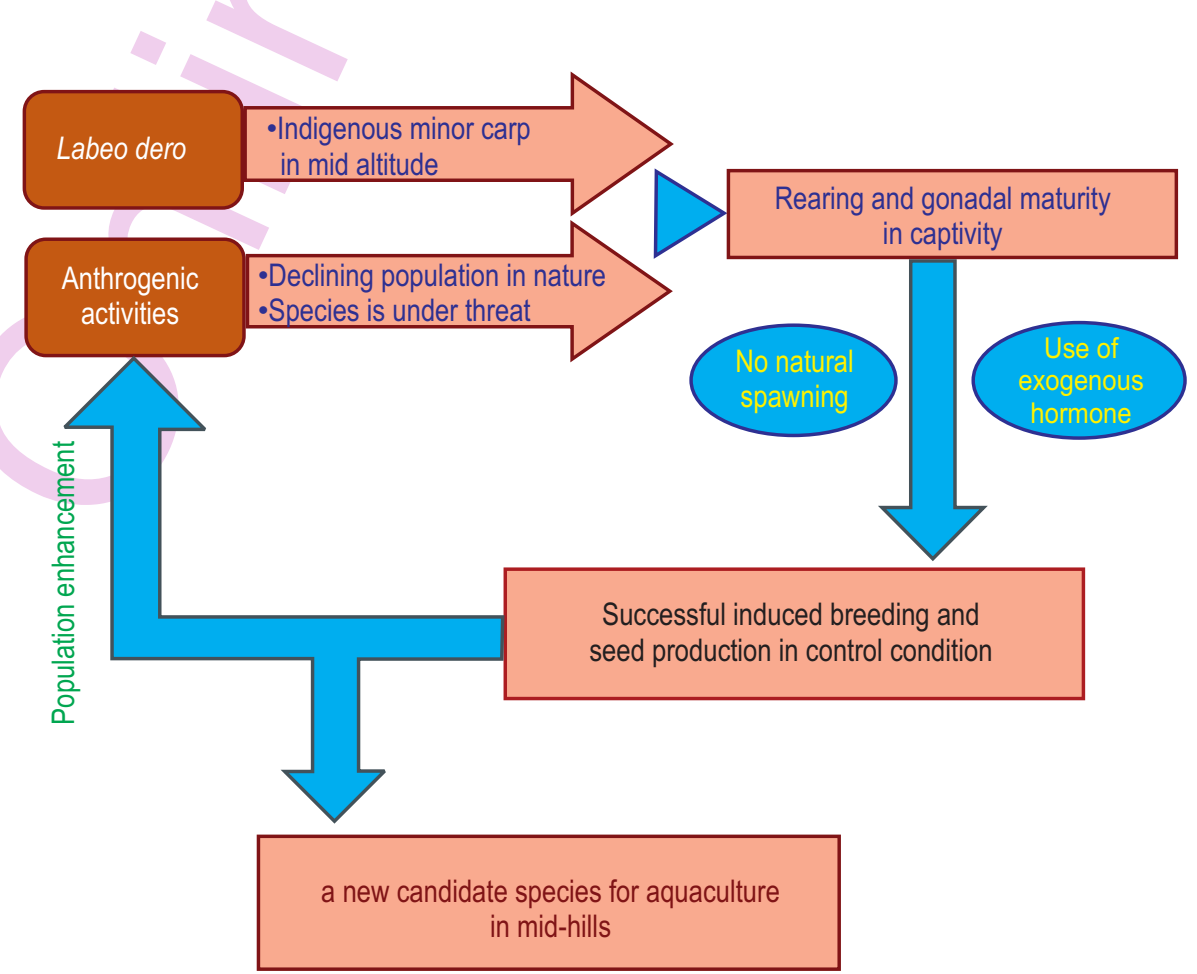




\section{Introduction}

Labeo dero commonly known as 'Kalabans' in India, 'Gardi' and 'Kathalegi' in Nepal, 'Kursa' in Bangladesh, is one of the popular food fish and is widely distributed all along the foot hill regions of Himalayan ranges of India, Pakistan, Bangladesh, Nepal, Myanmar and China (Talwar and Jhingran, 1991; Mohindra et al., 2005). The fish is ordinarily white in colour with more elongated body and relatively small head. In India, it is common in the Gangetic belt and Indus river systems. Its maximum reported length is around $750 \mathrm{~mm}$. It can be used in pond culture along with Indian major carps due to local market acceptance. The population of this species is struggling for its existence due to unplanned development projects of flood control and irrigation, dam construction, embankments, modification of river courses and other human activities and categorized as a vulnerable fish (Mahanta et al., 1994). Therefore, proper management initiatives of this species should be taken to save this fish in nature. To maintain the wild population of this fish in nature as well as its conservation, development of a suitable technology for captive breeding is urgently needed. Under captive condition, both, male and female attain gonadal maturity (Pandey et al., 2014), but do not spawn naturally.

Exogenous hormones such as pituitary gland extracts and others are commonly injected to mature brooders to induce breeding (Yaron, 2009). Due to the increasing cost of donor pituitary and cumbersome process, Human Chorionic Gonadotropin, Leutinizing Hormone Releasing Hormone and ovaprim are the alternatives of the pituitary extract (Haniffa and Sridhar, 2002). Ovaprim is a product that contains salmon gonadotropin releasing hormone analogue ( $\mathrm{sGnRH;D-}$ $\mathrm{Arg}^{6}{ }^{6} \mathrm{Pro}^{9}$,Net) at a concentration of $20 \mathrm{\mu gml}^{-1}$ and dompridone, a dopamine antagonist at $10 \mathrm{mg} \mathrm{ml}^{-1}$ (Hill et al., 2009). Dopamine antagonists are used for cessation of dopamine activity which acts as an inhibitory factor for the synthesis of gonadotropin (Naeem and Salam, 2005). Ovaprim is used to induce ovulation and spermiation in fish mostly by intramuscular or intraperitonial route (Nandeesha et al.,1990; Pandey and Singh, 1997; Raghav et al., 2012). In India, a breeding technique of cold water fish species, with or without hormone injection has been developed for T. khudree, T. putitora, T. tor and hybrid mahseer (Ogale and Kulkarni, 1987; Ogale, 2002; Sangma and Basavaraja, 2010). Attempts have been made to breed T. putitora (Golden mahseer) in the Kumaon region (Shyam sunder et al., 1993; Ogale, 1997). Breeding of Labeo dyocheilus has been achieved using ovaprim in cold water condition under captivity (Pandey et al., 2011). Captive breeding of Channa aurantimaculata in Assam is also described by Gogoi et al. (2016). There is only one report from the Nepal for semi artificial breeding of $L$. dero (Prasad, 2009). But no systematic research work has so far been undertaken on the breeding biology, breeding behavior and induced breeding of $L$. dero. Therefore, induced breeding approach was applied for successful spawning of captive reared brood fish. Hence, the present study was undertaken to develop the induced breeding techniques of this fish in captivity and under cold water conditions

\section{Materials and Methods}

The experiments were conducted at ICAR-Directorate of Coldwater Fisheries Research, Bhimtal, India. Immature fish of body weight 110-220 g were captured during January 2011 from the Kosi river, Ramnagar of Kumaon Himalayan region, India by local fishermen and transported to laboratory in 1000 I containers fitted with oxygen diffusers. The immature fish were reared for two year in the cemented tank under coldwater condition $\left(8-23.5^{\circ} \mathrm{C}\right)$ and fed daily with conventional carp feed (protein level 24\%) at $3 \%$ of their body weight. Fish were dissected and gonad was taken out individually from male and female and weighed on a single pan electronic balance to observe the maturity status. Gonadosomatic index of female were calculated from April to July.

After two years, the female brooders achieved 350 to 470 $\mathrm{g}$ weight and male achieved $210-250 \mathrm{~g}$ body weight and showed full maturity in pond environment with egg release and oozing milt from $3^{\text {rd }}$ week of July to the end of August. Mature females were selected by their bulging soft abdomen, oval shaped reddish vent slit and smooth pectoral fins, while mature males were selected by pale reddish vent slit and rough pectoral fins. One day before the experiment, the brooders were selected and transferred to FRP tanks $(2.5 \times 2.5 \times .75 \mathrm{~m})$ of $3125 \mathrm{I}$ capacity filled to a water level of $50 \mathrm{~cm}$. Each breeding set consisted of two male and one female. Both the sexes of this species did not respond to natural spawning in captive condition. Hence, the selected females were randomly assigned to four treatment groups (T1, T2, T3 and T4) and were injected intramuscularly with ovaprim hormone @ 0.3, $0.5,0.7,0.9 \mathrm{ml} \mathrm{kg}^{-1}$ body weight. All the males were injected with ovaprim hormone @ $0.2 \mathrm{ml} \mathrm{kg}^{-1}$ body weight simultaneously with female. The hormone was administered during evening at 18:00 hrs.

Hormone treated fish were introduced overnight into the FRP tanks and left to spawn. Darkness was maintained in tank by covering the tank with green colour net. After spawning, the number of eggs and rate of fertilization were calculated. Fertilized eggs from the breeding tanks were transferred carefully to trays having flow through systems for incubation. Rate of fertilization, hatching, incubation period and survival of larvae was observed for each operation.

The effect of different temperature on egg incubation performance and survival were also observed to optimize suitable temperature for successful incubation. For the experiment, one hundred of fertilized eggs were randomly selected and kept in glass jar with $1 \mathrm{I}$ of water. Water temperature was maintained at $16,18,20,22$ and $24^{\circ} \mathrm{C}$ each with three replicates. 16, 18 and $20^{\circ} \mathrm{C}$ were maintained by keeping the glass jar in $\mathrm{BOD}$ incubator. $24^{\circ} \mathrm{C}$ was maintained by electric heater controlled thermostatically and $22^{\circ} \mathrm{C}$ was the natural temperature of water at 
the time of experiment. The fertilization rate and hatching rate were calculated. Physico-chemical parameters of water were analyzed following the protocols of APHA (2012). During the experiment, the average water temperature, $\mathrm{pH}$ and dissolved oxygen were recorded as $18-22^{\circ} \mathrm{C}, 8.4-8.6$ and $6.4-8.0 \mathrm{mg} \mathrm{l}^{-1}$, respectively.

Statistical analysis of data was done by one way analysis of variance (ANOVA) and Duncan's New Multiple Range Test (DNMRT) to determine differences between the means taking at $1 \%(P<0.01)$ or $5 \%(P<0.05)$ significance levels. Results are presented as means \pm standard deviation.

\section{Results and Discussion}

In both the sexes, Gonadosomatic index (GSI) increased gradually from the month of April to July and decreased in the month of August, which showed gonadal maturity in captive condition. GSI ranged from $3.324 \pm 0.143$ to $14.115 \pm 1.214$ in captive reared females. Similar trend in GSI were recorded in $L$. dyocheilus (Singh et al., 2008; Pandey et al., 2011 and Gupta et al., 2013b) and in L. dero (Pandey et al., 2014) kept under captivity. In general, mature brooders did not show natural spawning in captivity, but, single intramuscular dose of synthetic hormone, ovaprim resulted in successful spawning of $L$. dero without post spawning mortality. Significantly, the highest $(P<0.05)$ spawning fecundity was obtained in T3 (ovaprim $0.7 \mathrm{ml}$ $\mathrm{kg}^{-1}$ body weight), than $\mathrm{T} 2$ (ovaprim $0.5 \mathrm{ml} \mathrm{kg}^{-1}$ body weight). The highest fertilization rate and hatching rate was also observed in
T3 (ovaprim $0.7 \mathrm{ml} \mathrm{kg}^{-1}$ body weight) group (Table 1). Therefore, hormone dose (ovaprim) of $0.7 \mathrm{ml} \mathrm{kg}^{-1}$ body wt. for females and $0.2 \mathrm{ml} \mathrm{kg}^{-1}$ body wt. for males was found optimum for successful spawning of captive reared $L$. dero. Similar results of induce breeding were reported in L. dyocheilus (Sarkar et al., 2004; Pandey et al., 2011).

A positive correlation was observed between body weight of fish and breeding performance. Females having average body weight of $0.430 \pm 0.04$ to $0.470 \pm 0.15 \mathrm{~kg}$ showed larger egg size, more fecundity, better fertilization rate and better hatching rate than the females of less body weight $(0.350 \pm 0.08$ to $0.390 \pm 0.06$ $\mathrm{kg}$ ) (Table 2). The latency period of $L$. dero ranged from $12-14 \mathrm{hrs}$ at $18 \pm 1.5^{\circ} \mathrm{C}$. These results are in conformity of $L$. dyocheilus administered with ovaprim (Pandey et al., 2011). In the present study, relative fecundity was observed as $1,47,343 \pm 110$ eggs kg 1. However, Prasad (2009) reported higher relative fecundity of $L$. dero with wild brooders. The fertilization rate of $90 \pm 2.5 \%$ and hatching rate of $78 \pm 4.5 \%$ was recorded in present study, which is comparable with L. dyocheilus (Sarkar et al., 2004; Singh et al., 2008 and Pandey et al., 2011) and L. bata (Hossain et al., 2007). Prasad (2009) also observed fertilization rate and hatching rate in L. dero, which was approximately similar to this study.

Egg incubation performance of $L$. dero is presented in Table 3. It was found that optimum temperature range for the egg incubation in coldwater conditions was $18-22^{\circ} \mathrm{C}$ with incubation period of 20-29 hrs, which is almost similar to incubation period of L. dyocheilus (18-30 hrs) reported by Gupta et al. (2013a). Prasad

Table 1 : Spawning performance of $L$. dero induced at different Ovaprim dosages $\left(\mathrm{ml} \mathrm{kg}^{-1}\right)$ at $18 \pm 1.5^{\circ} \mathrm{C}$

\begin{tabular}{|c|c|c|c|c|c|c|c|c|c|c|}
\hline & $\begin{array}{l}\text { ant Weight of } \\
\text { female } \\
(\mathrm{kg})\end{array}$ & $\begin{array}{l}\text { Weight of } \\
\text { male } \\
(\mathrm{kg})\end{array}$ & $\begin{array}{l}\text { Dose of } \\
\text { Ovaprim } \\
\left(\mathrm{ml} \mathrm{kg}^{-1}\right) \\
\text { female }\end{array}$ & male & $\begin{array}{l}\text { Latency } \\
\text { period }\end{array}$ & $\begin{array}{l}\text { Spawning } \\
\text { fecundity/kg } \\
\text { body weight }\end{array}$ & $\begin{array}{l}\text { Fertilization } \\
\text { rate }(\%)\end{array}$ & $\begin{array}{l}\text { Incubation } \\
\text { period }\end{array}$ & $\begin{array}{l}\text { Hatching } \\
\text { rate }(\%)\end{array}$ & Remark \\
\hline$\overline{\mathrm{T} 1}$ & $0.450 \pm 0.05$ & $0.250 \pm 0.05$ & 0.3 & 0.2 & - & - & - & - & - & No spawning \\
\hline T2 & $0.415 \pm 0.09$ & $0.210 \pm 0.04$ & 0.5 & 0.2 & $14-16$ & $20,330 \pm 145^{b}$ & $72 \pm 2.0^{b}$ & $20-24^{a}$ & $55 \pm 5.0^{\mathrm{b}}$ & Partial spawning \\
\hline T3 & $0.440 \pm 0.04$ & $0.240 \pm 0.06$ & 0.7 & 0.2 & $12-14$ & $1,44,500 \pm 210^{\mathrm{a}}$ & $90 \pm 5.5^{\mathrm{a}}$ & $21-26^{a}$ & $74 \pm 3.5^{\mathrm{a}}$ & Complete spawning \\
\hline T4 & $0.410 \pm 0.15$ & $0.213 \pm 0.05$ & 0.9 & 0.2 & - & - & - & - & - & No spawning \\
\hline
\end{tabular}

Means with different superscript within the same group are significantly different $(P<0.05)$

Table 2 : Breeding performance of $L$. dero in relation to body weight of females at $18 \pm 1.5^{\circ} \mathrm{C}$

\begin{tabular}{|c|c|c|c|c|c|c|c|c|c|}
\hline \multirow{2}{*}{$\begin{array}{l}\text { Weight of } \\
\text { female } \\
(\mathrm{kg})\end{array}$} & \multirow{2}{*}{$\begin{array}{l}\text { Weight of } \\
\text { male } \\
(\mathrm{kg})\end{array}$} & \multicolumn{2}{|c|}{$\begin{array}{l}\text { Dose of } \\
\text { Ovaprim }\end{array}$} & \multirow[t]{2}{*}{$\begin{array}{l}\text { Egg size } \\
(\mathrm{mm})\end{array}$} & \multirow{2}{*}{$\begin{array}{l}\text { Spawning } \\
\text { fecundity/kg } \\
\text { body weight }\end{array}$} & \multirow[t]{2}{*}{$\begin{array}{l}\text { Fertilization } \\
\text { rate(\%) }\end{array}$} & \multirow[t]{2}{*}{$\begin{array}{l}\text { Incubation } \\
\text { period }\end{array}$} & \multirow[t]{2}{*}{$\begin{array}{l}\text { Hatching } \\
\text { rate (\%) }\end{array}$} & \multirow[t]{2}{*}{ Remark } \\
\hline & & female & male & & & & & & \\
\hline $0.350 \pm 0.08$ & $0.260 \pm 0.05$ & 0.7 & 0.2 & $1.6^{b}$ & $51,650 \pm 145^{b}$ & $69 \pm 2.5^{b}$ & $21-26^{a}$ & $55 \pm 4.0^{b}$ & spawning \\
\hline $0.390 \pm 0.06$ & $0.250 \pm 0.06$ & 0.7 & 0.2 & $1.8^{b}$ & $58,000 \pm 188^{b}$ & $72 \pm 2.0^{b}$ & $21-24^{\mathrm{a}}$ & $65 \pm 4.4^{b}$ & Partial spawning \\
\hline $0.430 \pm 0.04$ & $0.250 \pm 0.05$ & 0.7 & 0.2 & $2.8^{\mathrm{a}}$ & $1,34,500 \pm 210^{a}$ & $92 \pm 5.5^{\mathrm{a}}$ & $21-26^{a}$ & $74 \pm 3.5^{\mathrm{a}}$ & Complete spawning \\
\hline $0.470 \pm 0.15$ & $0.243 \pm 0.08$ & 0.7 & 0.2 & $2.6^{\mathrm{a}}$ & $1,47,343 \pm 110^{a}$ & $90 \pm 2.5^{\mathrm{a}}$ & $21-26^{a}$ & $78 \pm 4.5^{\mathrm{a}}$ & Complete spawning \\
\hline
\end{tabular}

Means with different superscript within the same group are significantly different $(P<0.05)$ 
Table 3 : Egg incubation performance of $L$. dero at different temperature

\begin{tabular}{lllll}
\hline Temperature $\left({ }^{\circ} \mathrm{C}\right)$ & \multicolumn{2}{c}{ Incubation period } & Hatching rate (\%) & Survival rate (\%) \\
& Hatching start(hr) & Hatching completed $(\mathrm{hr})$ & & $4.0 \pm 0.0^{\mathrm{C}}$ \\
16 & 29 & 48 & $9 \pm 1.0^{\mathrm{c}}$ & $65 \pm 2.0^{\mathrm{a}}$ \\
18 & 24 & 28 & $71 \pm 3.5^{\mathrm{a}}$ & $72 \pm 2.0^{\mathrm{a}}$ \\
20 & 22 & 29 & $74 \pm 4.0^{\mathrm{a}}$ & $70 \pm 3.0^{\mathrm{a}}$ \\
22 & 20 & 24 & $73 \pm 3.0^{\mathrm{a}}$ & $60 \pm 4.0^{\mathrm{b}}$ \\
24 & 16 & 19 & $66 \pm 3.0^{\mathrm{b}}$ & \\
\hline
\end{tabular}

Means with different superscript within the same group are significantly different $(P<0.05)$

et al. (2009) reported shorter incubation period (16-18 hrs) of $L$. dero at $24-26^{\circ} \mathrm{C}$. Kikko et al. (2015) reported that lower incubation temperature resulted in smaller hatchling size and longer time to hatch.

The average size of one day hatchling was found to be $3.24 \pm 0.48 \mathrm{~mm}$, weighing $0.005 \mathrm{~g}$. Yolk material was absorbed within $70-84 \mathrm{hrs}$ of hatching at $22^{\circ} \mathrm{C}$ temperature and larvae started external feeding on $4^{\text {th }}$ day. The survival percent of hatchling (72\%) was comparatively higher than the survival percent (24.1\%) as reported by Prasad (2009) in L. dero. The results of the present investigation demonstrate successful induce breeding of captive reared $L$. dero at $18-22^{\circ} \mathrm{C}$ water temperature.

These findings would be helpful for seed production of $L$. dero which can be used for natural stock augmentation and culture of this species. Finally, it is concluded that the success in seed production would be helpful for developing $L$. dero as a new candidate species for the coldwater aquaculture practice.

\section{Acknowledgments}

The authors express sincere gratitude to the Principal Chief Conservator of Forests (Wild Life), Forest Department, Govt. of Uttarakhand for permission to collect wild brooders from Kosi stream. They are also grateful to the Director, DCFR, Bhimtal for providing facilities and able guidance to carry out the study.

\section{References}

APHA: Standard methods for the examination of water and wastewater. $22^{\text {nd }}$ Edn., American Public Health Association, Washington DC, USA(2012).

Gogoi, N., L.P. Hazarika and S.P. Biswas: Studies on the reproductive biology and captive breeding of Channa aurantimaculata, an endemic fish from Assam. J. Environ. Biol., 37, 369-374 (2016).

Gupta, M., N.N. Pandey, R. Singh, P. Kumar, R.S. Haldar, S. Ali, S. Kumar and A. Pandey: Effects of different temperature on incubation period, hatching rate, survival and growth of Labeo dyocheilus larvae. J. Ecophysiol. Occup. Hlth., 1 \& 2, 59-62 (2013a).

Gupta, M., N.N. Pandey, V.K. Tiwari, R. Singh, C. Prakash and C.S. Chaturvedi: Study of gonadosomatic index and fecundity of pond raised Labeo dyocheilus in cold water conditions. Int. J. Adv. Res.,

\section{$1,137-140$ (2013b).}

Haniffa, M.A.K. and S. Sridhar: Induced spawning of spotted murrel (Channa punctatus) and Catfish (Heteropneustes fossilis) using human chorionic hormone and synthetic hormone Ovaprim. VeterinarskiArch., 72, 51-56 (2002).

Hill, J.E., K.H. Kilgore and B.D. Pouder: Survey of Ovaprim use as a spawning aid in ornamental fishes in the United States as administered through the University of Florida Tropical Aquaculture Laboratory. North Ameri. J. Aquat., 71, 206-209 (2009).

Hossain, Q.Z., M.A. Hossain and S. Parween: Breeding performance and nursery practices of Labeo bata (Hamilton-Buchanan, 1822). Scientific World, 5, 40-45 (2007).

Kikko, T., T. Usuki, D. Ishizaki, Y. Kai and Y. Fujioka: Relationship of egg and hatchling size to incubation temperature in the multiplespawning fish Gnathopogon caerulescens (Honmoroko). Environ. Biol. Fishes, 98, 1151-1161 (2015).

Mahanta, P.C., D. Kapoor, R. Dayal and A.G. Ponniah: Prioritization of the Indian fish species for conservation. In: Threatened Fishes of India (Eds.: P.V. Dehadrai, P. Das and S.R. Verma). Proc. National Seminar on Endangered Fishes of India, Nature Conservators, pp. 377-386 (1994).

Mohindra, V., P. Punia, L. Narain, D. Kapoor and K. K. Lal: Microsatellite loci to determine population structure of Labeo dero (Cyprinidae). Aqu. Living Reso., 18, 83-85 (2005).

Naeem, M. and A. Salam: Induced spawning of bighead carp Aristichthys Nobilis by using ovaprim-cat fish hatchery Islamabad, Pakistan. Sindh. Univ. Res. J. (Sci.Ser), 37, 9-16 (2005).

Nandeesha, M.C., K.G. Rao, R. Jayanna, N.C. Parker, T.J. Varghese, P. Keshavanath and H.P.C. Shetty: Induced spawning of Indian major carps through single application of Ovaprim. In: The second Asian Fisheries Forum (Eds.: R. Hirano and M. Hanyu). Asian Fisheries Society, Manila, Philippines, pp. 581-585 (1990).

Ogale, S.N. and C.V. Kulkarni: Breeding of pond raised hybrids of Mahseer fish, Tor khudree (Sykes) and Tor tor (Ham.). J. Bombay Nat. Hist. Soc., 84, 332-335 (1987).

Ogale, S.N.: Induced spawning and hatching of golden mahseer, Tor putitora (Hamilton) at Lonavala, Pune ( Mahrastra) in Western Ghat. Fishing Chimes, 17, 27-29 (1997).

Ogale, S.N.: Mahseer ranching. In: Riverine and Reservoir Fisheries of India (Eds.: M.R. Boopendranath, B. Meenakumari J. Joseph, T. V. Sankar, P. Pravin and L. Edwin) pp. 225-229 (2002).

Pandey, A.C. and R.N. Singh: Breeding of Catla catla (Bhakur), Labeorohita (Rohu) and Cirrhinus-mrigala (Nain) by ovaprim injection for quality seed production. J.Adv. Zool., 18, 38-41(1997).

Pandey, N.N., R.S. Haldar, S. Ali, P. Kumar, R.S. Patiyal and P.C. 
Mahanta: Induced spawning of Labeo dyocheilus in captivity under cold water condition. J. Inland fish Soc. India, 43, 44-48 (2011).

Pandey, N.N., R.S. Haldar, M. Gupta and R. Singh: Study of gonadosomatic index and absolute fecundity of Labeo dero (Hamilton, 1822). J. Sust. Envir. Res., 3, 47-50 (2014).

Prasad, S.: Nursery Practices of Hatchery Bred Riverine Gardi (Labeo dero) in Captive environment in Mid Hill Valley and River Basin. In: Proceedings of $7^{\text {th }}$ National Workshop on Livestock and Fisheries Research, (Eds.: B.S. Shrestha, U.M. Singh, M.P. Aryal, T.P. Paudel and C.R. Upreti). National Animal Science Research Institute(NASRI), Khumaltar, pp. 45-48 (2009).

Raghav, M., M.S. Chari and S.S. Mishra: Induced spawning and hatching rate of Grass Carp (Ctenopharyngodon idella) by using a single intramuscular injection of ovaprim at Demar fish hatchery Dhamtari (C.G). India. Res. J. Sci. Tech., 4, 28-31 (2012).

Sangma, K.O.N. and N. Basavaraja: Induced breeding, embryology and rearing of fry of deccan mahseer, Tor khudree (sykes). J. Aqua Trop., 25, 13-24 (2010).
Sarkar, U.K., R.S. Negi, P.K. Deepak, S.P. Singh, S.M. Srivastava and D. Roy: Captive breeding of vulnerable Indian carp Cirrhinus reba with Ovaprim for conservation of wild populations. Aquaculture Asia, 9, 5-7 (2004).

Sunder, S., M. Mohan, H.S. Raina, R. Singh and R.S. Halder: Culture of golden mahseer, Tor putitora (Hamilton) in Kumaon Himalaya. Mass scale production of stocking material. In: Proceedings of Third Indian Fisheries Forum, pp.45-48 (1993).

Singh, A., I.J. Singh, R.N. Ram and B. Kushwaha: Ovarian development in Labeo dyocheilus (McClelland) during active reproductive phase under captive and wild conditions. J. Environ. Biol., 29, 16974 (2008).

Talwar, P.K. and A.G. Jhingran: Inland fishes of India and adjacent countries. Vol. 1.A.A. Balkema, Rotterdam, p. 541 (1991).

Yaron, Z., A. Bogomolnaya, S. Drori, I. Biton, J. Aizen, Z. Kulikovsky and B. Levavi-Sivan: Spawning induction in the carp: past experience and future prospects - a review. Israeli J. Aquacul.Bamidgeh, 61, 526 (2009). 